\title{
Jurnal

\section{ANTICANCER EFFECTS OF RETINOIC ACID IN CERVICAL CANCER CELLS}

\author{
Sugania Malar Chinapayan, Praseetha Prabhakaran* \\ Department of Biosciences, Faculty of Science, Universiti \\ Teknologi Malaysia, 81310 UTM Johor Bahru, Johor, Malaysia
}

Article history

Received

9 January 2018

Received in revised form

5 November 2018

Accepted

1 December 2018

Published online

18 February 2019

*Corresponding author praseetha@fbb.utm.my

\section{Graphical abstract}

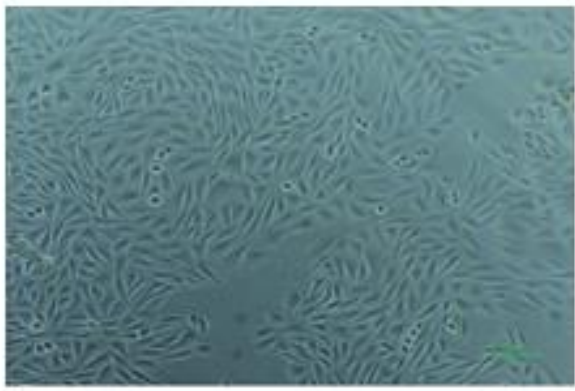

Morphology of HeLa cells cultured without Retinoic acid after 24 hours treatment (control)

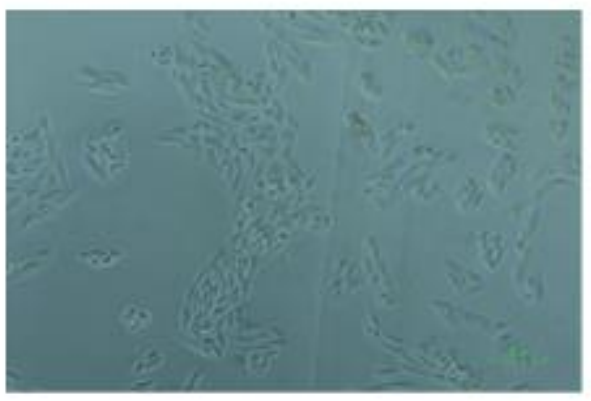

Morphology of HeLa cells cultured with $10 \mu M$ Retinoic acid after 24 hours treatment

\begin{abstract}
Cervical cancer is a leading cause of cancer-related death in women, and it is known to have a poor prognosis. This is because, patients develop progressive or recurrent tumours after primary treatment, and the major reason for tumour recurrence is the presence of cancer stem cells (CSCs). It is known that retinoic acid (RA) has potential therapeutic effects on cervical cancer. However, the possible mode of action of RA in cervical cancer cells, and its relation to CSCs remains elusive. The aim of this research was to determine the anticancer effect of RA in cervical cancer cells (HeLa). HeLa cells were treated by various concentrations of RA ranging from 5-50 $\mu \mathrm{M}$ to determine the effect of RA on cell viability, and cell proliferation. Both experiments were carried out using Celltiter-glo 2.0 assay and CyQuant NF assay, respectively. Apoptosis activity was determined using Caspase-Glo $3 / 7$ assay. Immunofluorescent staining was conducted to detect the expression of differentiation marker (pan-keratin), and stem cell markers

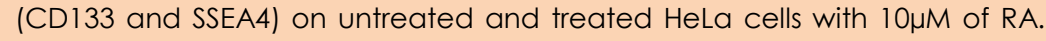
The findings showed that RA reduced cell viability and proliferation in a dose-dependent manner by $12-83 \%$ and $22-86 \%$, respectively. However, a change in caspase $3 / 7$ activity between untreated, and 10 $\mu \mathrm{M}$ RA-treated Hela cells were not detected indicating absence of apoptotic activity. The study also revealed that expression of differentiation marker (pan-keratin) was up-regulated, while expressions of stem cell markers (CD133 and SSEA4) were down-regulated. In addition, morphology of HeLa cells displayed a more differentiated phenotype that is less proliferative upon RA treatment. These findings suggest that RA showed its anticancer effect on cervical cancer cells by exhibiting cytotoxicity, inhibiting proliferation capacity, and inducing differentiation of cervical cancer cells. This finding shows that retinoic acid may potentially serve as a potent targeted therapy for cervical cancer and other cancers possessing CSCS within its tumors.
\end{abstract}

Keywords: Cervical cancer, anti-cancer, retinoic acid, cancer stem cells (CSCs), differentiation 


\begin{abstract}
Abstrak
Kanser serviks adalah punca utama kematian di kalangan wanita, dan mempunyai prognosis yang kurang efektif. Ini kerana, pesakit mengalami tumor progresif selepas rawatan dan menyebab utama tumor progresif adalah, disebabkan sel kanser stem (CSC). la telah diketahui bahawa, retinoic asid (RA) mempunyai kesan terapeutik terhadap kanser serviks. Tujuan kajian ini adalah, untuk menyiasat kesan antikanser retinoic asid dalam rawaten sel kanser serviks. Dalam kajian ini, sel-sel HeLa telah dirawat

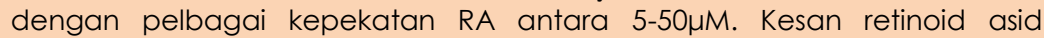
terhadap viabiliti dan prolifarasi sel HeLa, telah dikaji menggunakan celltiterGlo 2.0 assay dan CyQuant NF assay. Manakala, aktiviti apoptosis telah dikaji menggunakan Caspase-Glo $3 / 7$ assay. Kesan retinoic asid terhadap pelbagai penanda seperti (pan-keratin) dan (CD133 dan SSEA4) telah dikaji. RA menunjukkan kesan anti-kanser kanser terhadap sel-sel kanser serviks dengan mengurangkan viability sehingga $12-83 \%$ dan proliferasi sel kanser sehingga $22-86 \%$. Namun, RA tidak menunjukkan aktiviti apoptosis terhadap sel kanser. RA meningkatan ekspresi penanda (pan-keratin) dan pengurangan eksprasi penanda (CD133 dan SSEA4) dan perbezaan morfologi sel HeLa selepas rawatan RA membuktikan kesan anti-kanser RA. Kesimpulannya, RA menunjukkan kesan anti-kanser, dengan menghalang keupayaan proliferasi dan viabiliti dan mendorong pembezaan sel-sel kanser serviks. Oleh itu, asid retinoic berpotensi sebagai terapi sasaran untuk kanser serviks.

Kata kunci: Kanser servix, anti-kanser, asid retinoic, sel kanser stem (CSCs), pembezaan
\end{abstract}

(C) 2019 Penerbit UTM Press. All rights reserved

\subsection{INTRODUCTION}

Cervical cancer is the third common female disease worldwide after breast and colorectal cancer, with about half a million cases a year with $80 \%$ cases in less-developed countries, and about $25 \%$ in developing countries $[1,2]$. The main cause of cervical cancer is the Human papillomavirus (HPV) infection [1]. HPV is a virus that is transmitted sexually [3]. Although, most HPV infection is harmless and clears spontaneously, persistent infection with highrisk human papillomavirus subtype, especially type 16 and type 18 greatly increases the risk of cervix cancer [4, 5]. HPV virus infects epithelial cells, and induce hyperproliferative lesions [6].

The current treatment strategies for cervical cancer are electro-surgery and cryosurgery (remove and cure premalignant lesions), while chemotherapy and radiotherapies are usually used for high-risk premalignant lesions, and carcinomas [7]. However, the major problem with current treatments is that patients with cervical cancer showed tumour recurrence where the tumour characteristics become more malignant after treatment [7]. The main reason for tumour recurrence is pressumed to be due to the population of cancer stem cell (CSC) within the tumour. In the cervix, the de-differentiation of mature cells, and mutation of stem cells in normal cervical tissue is believed to be the source of cervical cancer stem cells [8]. Based on previous studies, CSCs have been identified in several cervical cancers cell line such as SiHa, CaLo, C-33A [9]. CSCs have properties similar to normal stem cells such as self-renewal, slow cycling capacity, multilineage differentiation potential, asymmetric division, and tumorigenicity $[10,11]$.

All traditional chemotherapies target proliferating cells, potentially missing the slower dividing CSCS within a tumour, allow the CSCs to survive, and be resistant to treatment. These abilities of the CSCs are responsible for tumour metastasis, relapse, and chemo/radio-resistance as a result of reactivation of proliferation by the surviving CSCs post treatment [12]. Therefore, it is necessary to identify effective drugs to target CSC enriched cervical cancer, which are still difficult to treat, and lack effective treatment for cervical cancer [10].

As it is known that stem cells differentiate into more matured/specialised cells with limited proliferative capacity, current anti-cancer drug treatments are focused more on establishing differentiation based therapies [13]. The principle of differentiation therapies is to convert CSC population within a tumour into a more differentiated phenotype, and to make them respond to a second drug, or therapy that targets differentiated cancer cells [13].

Retinoic acid is a metabolite of vitamin A. Retinoic acid was previously discovered to have potential in preventing cancer development. The function of this compound in biological processes are maintenance of epithelial cell, differentiation, proliferation, and apoptosis [14]. It also acts as inhibitors of chemical and viral carcinogenesis [14]. Previous studies on 
retinoic acid showed that it suppressed the growth, and development of various types of tumors such as skin, bladder, lung, prostate, and breast cancers [15]. Besides that, addition of retinoic acid to human tumour xenograft in mice resulted in growth arrest, and differentiation of tumour cells $[16,17]$. Previous studies also reported that retinoic acid, a promising chemotherapy agent in acute promyelocytic leukemia (APL), destroys the fusion oncogene such as autophagy [17]. In acute promyelocytic leukemia patients, retinoic acid-induced apoptosis mediated by paracrine action of tumour-selective death ligand TRAIL [18]. Moreover, retinoic acid in combination with histone deacetylase inhibitors SL 14 has an antitumour effect, and is a therapeutic candidate to treat lung cancer [19].

Thus, an understanding of anti-cancer effect of retinoic acid in cervical cancer cells, is important for developing the usage of retinoids in therapeutic trials. However, the action/mechamnism of retinoic acid in cervical cancer still remains unclear. Therefore, this project looks into the anti-cancer effect of retinoic acid, and its possible mechanism of action based on the ability to induce apoptosis in cervical cancer cells

\subsection{METHODOLOGY}

\subsection{Cell Culture}

Cervical cancer cell line (Hela cells) were cultured in T25 flasks and maintained at $37^{\circ}$ and $5 \%$ of $\mathrm{CO}_{2}$ in DMEM/F12+Glutamax ${ }^{T M} 1$ (Life Technologies, USA), supplemented with fetal calf serum (FCS), and antibiotic-antimycotic $(100 \mathrm{U} / \mathrm{mL}$ penincilin, $100 \mu \mathrm{g}$ of streptomycin $/ 0.25 \mu \mathrm{g} / \mathrm{ml}$ ) (Invitrogen). Cervical cancer cell line (Hela cells) was passaged, three times a week at $60-70 \%$ cell confluency.

\subsection{Determination of Cell Viability and Proliferation}

$60-70 \%$ confluency of cell cultures were used to test cell viability (cytotoxicity) and proliferation. 4×103 cells per 100- $\mu$ l were seeded in a 96-well plate. After 24 hours of incubation, retinoic acid was added at

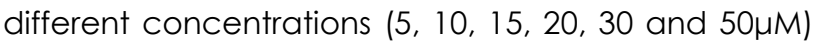
and incubated for 24 hours. Examination of cell viability was done via Celltiter-Gloß 2.0 Assay kit. 100$\mu$ l of celltiter-glo® 2.0 reagent was added per well and contents were mixed for 2 minutes on a vortex mixer. To stabilize luminescent signal, plate was incubated for 10 minutes before the reading was taken. Meanwhile, the cell proliferation was examined via Cyquantß NF assay kit. Old media was removed post 24 hours of RA treatment. Cells were then resuspended in 50 $\mathrm{LL} 1 \times$ Hank's Balanced Salt Solution (HBSS). 50ul $2 \times$ dye binding solution (CyQuant) was dispensed into each well containing cell culture. The microplate well were covered and incubated at $37^{\circ} \mathrm{C}$ for 2 hours before reading was taken. The activity for both the assays was read at $490 \mathrm{~nm}$ by installing a blue filter using a GloMax®-Multi Microplate Multimode Reader (Promega GloMax®Multi Detection System). Experiments were done in three independent experiments and the results were averaged.

\subsection{Caspase-Glo® 3/7 Apoptosis Assay System}

Cell cultures of $60-70 \%$ confluency were used for the apoptosis assay. $4 \times 10^{3}$ cells per $100-\mu$ l were seeded in a 96-well plate. The cells were incubated for 24 hours. After that, 10 $\mathrm{MM}$ of retinoic acid and $20 \mathrm{nM}$ of taxol was added, respectively, and the cells were

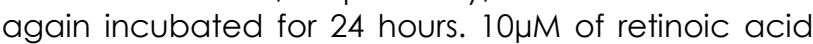
was selected as it showed $50 \%$ reduction in cell proliferation assay. After 24 hours of incubation, 96well plate containing cultured cells were equilibrated to room temperature. Caspase-Glo® 3/7 reagent was added to each well that contained control, $10 \mu \mathrm{M}$ of retinoic acid, and $20 \mathrm{nM}$ of taxol. The plate wells were covered and mixed gently, and incubated for 2 hours at room temperature. Fluorescence intensity of samples was measured at $490 \mathrm{~nm}$ by installing a blue filter using a GloMax®-Multi Microplate Multimode Reader (Promega GloMax®Multi Detection System). Caspase activity luminescence (RLU) percentage of apoptosis for control (untreated cell) was set to $1 \%$ which indicated natural apoptosis activity whereas the retinoic acid and taxol (positive control; apoptosis inducing drug) treated Hela cells apoptotic activity levels were normalised to the control.Experiments were done in three independent experiments and the results were averaged.

\subsection{Immunofluorescence Microscopy}

\subsubsection{Staining of Intracellular Marker (Pan-Keratin) and Surface Marker (CD133 and SSEA4)}

Hela cells were stained with Intracellular marker (pankeratin) to detect the presence of differentiation and surface markers (CD133 and SSEA4) to detect the stemness via presence of CSCs in untreated, and RA treated HeLa cells. In 24-well plates, $4 \times 10^{4}$ cells per $500 \mathrm{ml}$ were grown separately on coverslips for 24 hours. $10-\mu \mathrm{M}$ of retinoic acid was added, and the cells were incubated for 24 hours. The cells were then fixed with $1 \%$ of paraformaldehyde (PFA) in FCS $1 \%$ for 20 minutes. The over slips were washed once with PBS (phosphate-buffered saline) per well, and transferred to new 24 well plates. For intracellular marker, the cells were permeabilized by adding $0.1 \%$ of Triton X-100 (Calbiochem) in PBS for 20 minutes, and washed once with PBS prior to the addition of primary antibody. The primary antibodies anticytokeratin antibody (CK3-6H5 FITC, human), (CD133/1-VioBright (TM) FITC) and (anti-SSEA4-FITC, human) were added into each well, and incubated overnight in a dark area. The cells were washed with 
PBS. Secondary antibodies, mouse-IgG1- viobright FITC, and REA control(s) FITC along with 1:1000 (DAPI) for nuclear staining were added to the cells and incubated for another 2 hours. The cells were then washed with PBS, and the cover-slips were transferred on to slides with mounting medium (Dako), and sealed with nail polish. Appropriate negative control (secondary antibody only) was used for this study. The cells were imaged by using an inverted immunofluorescence microscopy.

\subsection{Statistical Analysis}

Statistical and graphical analysis was done in Microsoft Excel and GraphPad Prism-7. Paired t-test with two-tailed distribution was used to compare retinoic acid-treated and untreated cervical cancer cells. The results are presented in a mean $\pm S E M$ for (cytotoxicity, cell proliferation and apoptosis (caspase activity)). The significance is shown as follows: * $\mathrm{p}<0.05$; ** $\mathrm{p}<0.01$; *** $\mathrm{p}<0.001$; *** $\mathrm{p}<$ 0.0001 .

\subsection{RESULTS AND DISCUSSION}

\subsection{Retinoic Acid Reduces Cell Viability and Proliferation of Cervical Cancer Cells}

Cell viability of HeLa cells was determined using CellTiter-Glo® 2.0 Assay. Based on Figures 1, 2 and 3, retinoic acid showed a dose-dependent effect in Hela cells. As shown in Figure 1, retinoic acid at doses 5,10 , and $15 \mu \mathrm{M}$ showed a small decline in cell viability, which indicates a minimal level of cytotoxic effect in HeLa cells, ranging from 12-21\%. However, the most significant reduction in cell viability was observed at $50 \mu \mathrm{M},(83 \%, \mathrm{p}<0.01)$, followed by $30 \mu \mathrm{M}$, (59\%, $p<0.01)$, and $20 \mu \mathrm{M},(36 \%, p<0.01)$. This result showed that retinoic acid significantly exhibited cytotoxicity effect towards HeLa cells at higher doses $(20,30$ and $50 \mu \mathrm{M})$. To elucidate whether retinoic acid inhibited cell proliferation, the proliferation activity of HeLa cells was determined.

As shown in Figure 3, cell proliferation capacity showed a dramatic decrease in comparison to the cell viability at all doses of retinoic acid $(5,10,15,20$,

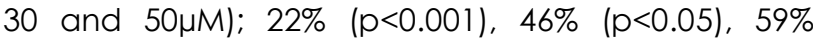
$(p<0.05), 62 \% \quad(p<0.01), 73 \% \quad(p<0.001)$ and $86 \%$ $(p<0.0001)$, respectively. The marked reduction in cell proliferation despite being viable may suggest that the surviving HeLa cells may have undergone differentiation. Based on a previous study it demonstrated that inhibition of cell growth can be the early indications of induced differentiation in cultured neuroblastoma cells [20].

In addition, the morphological changes in HeLa cells upon retinoic acid treatment showed a more differentiated phenotype that is less proliferative (see Figure 4). The cell density began to decrease and the cells that were exposed to higher doses of retinoic acid lost their normal morphology and shape; HeLa cells appeared slightly rounded in shape, and contracted with the increasing concentration of retinoic acid. At 30 and $50 \mu \mathrm{M}$ of retinoic acid, most of the cells appeared almost round in shape, which can be presumed that the surviving cancer cells could be cancer stem cells (CSCS) that are drug resistant (see Figure 4). The CSCs are known to live longer, are resistant to the effects of drugs, and have a quiescent slow-cycling phenotype [12, 21, 22].

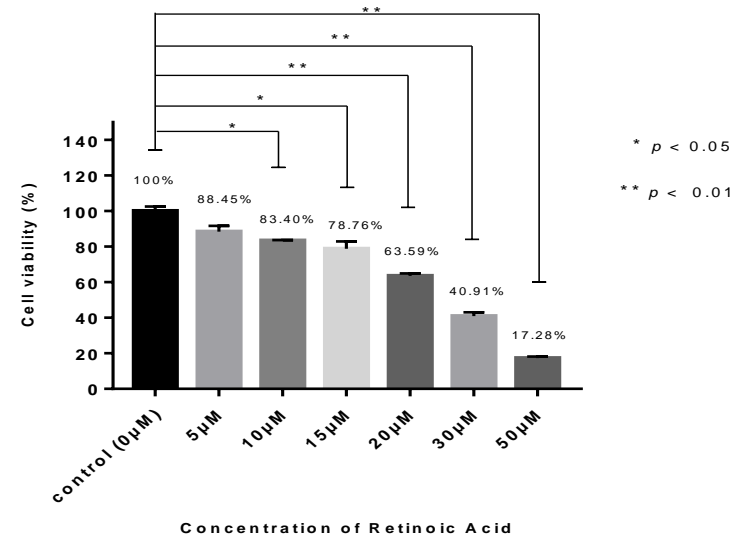

Figure 1 Analysis on the effects of growth inhibition activity of retinoic acid at increasing concentrations $(5,10,15,20$, 30 and $50 \mu \mathrm{M}$ ) on cell viability which was determined by cell-titer Glo 2.0 assay

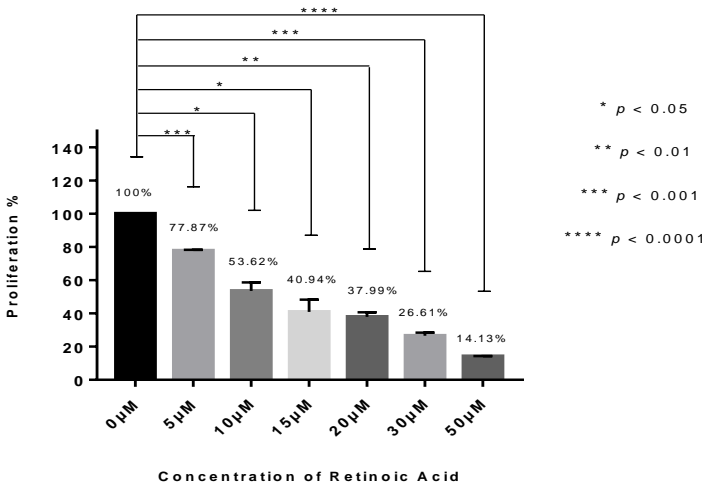

Figure 2 Analysis on the effects of growth inhibition activity of retinoic acid at increasing concentrations $(5,10,15,20$, 30 and $50 \mu \mathrm{M}$ ) on proliferation towards cervical cancer cells which was determined by CYQUANT NF assays 


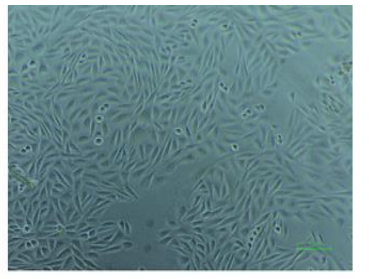

control
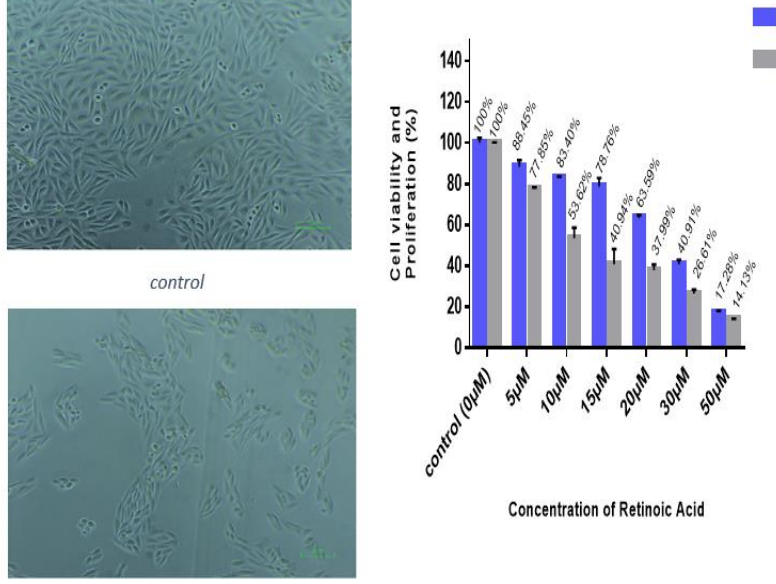

Concentration of Retinoic Acid

10uM Retinoic acid

Figure 3 Analysis on the effects of growth inhibition activity of retinoic acid at increasing concentrations $(5,10,15,20$, 30 and $50 \mu \mathrm{M})$ on cell viability and proliferation towards cervical cancer cells. Bar chart showed, retinoic acid reduces cell viability and proliferation in cervical cancer cells at increasing concentrations

Figure 3 shows the morphology of HeLa cells cultured with and without $10 \mu \mathrm{M}$ of retinoic acid $(10 \mu \mathrm{M}$ of retinoic acid showed $50 \%$ reduction in cell proliferation) after 24 hours of treatment. The images were obtained using Nikon eclipse TS 100 inverted microscope at 10X magnification; scale bar: $100 \mu \mathrm{m}$. Experiments were done in triplicate in three independent experiments and the results were averaged. Bars are presented as mean $\pm \operatorname{SEM}(n=3)$. ${ }^{*} \mathrm{p} \leq 0.05,{ }^{* *} \mathrm{p} \leq 0.01,{ }^{* * *} \mathrm{p} \leq 0.001,{ }^{* * * *} \mathrm{p} \leq 0.0001$.

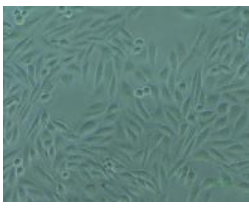

control

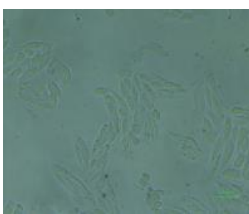

$15 \mu \mathrm{M}$ retinoic acid

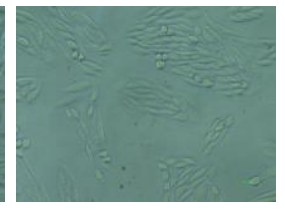

$5 \mu M$ retinoic acid

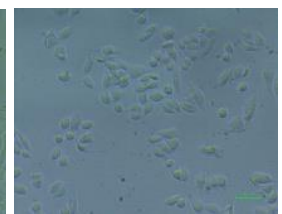

$20 \mu \mathrm{M}$ retinoic acid

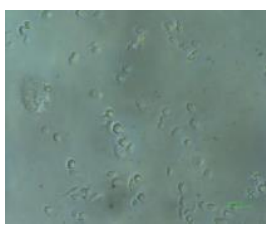

$50 \mu \mathrm{M}$ retinoic acid

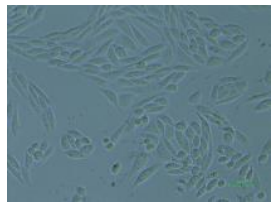

$10 \mu \mathrm{M}$ retinoic acid

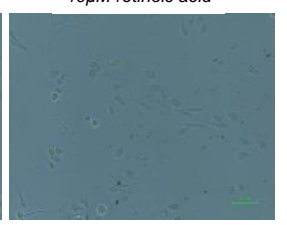

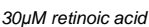

Figure 4 Morphology of HeLa cells post 24 hours treatment with $0,5,10,15,20,30$ and $50 \mu \mathrm{M}$ of retinoic acid (RA) after 24 hours. The morphological changes induced by RA became increasingly visible and were found to be dose dependent. The images were captured at $20 \mathrm{X}$ magnification; scale bar: $100 \mu \mathrm{m}$

\subsection{Retinoic Acid Did Not Induce Apoptosis in Cervical Cancer Cells}

Apoptosis is a physiological function of programmed cell death, and is characterised by distinct morphological characteristics such as cell shrinkage, chromatin condensation, dense cytoplasm, blebbing of plasma membrane, loss of nuclear membrane integrity, and eventually apoptotic bodies forms [23]. $10 \mu \mathrm{M}$ of retinoic acid was selected for apoptosis assay as it showed $50 \%$ reduction in cell proliferation assay (Figure 2). Treatment with 10 $\mu \mathrm{M}$ of retinoic acid $(0.98 \%)$ showed negligible changes in apoptosis induction, while $20 \mathrm{nM}$ of taxol $(1.71 \%)$ showed clear and significant increase in caspase $3 / 7$ activity which indicates apoptosis.

In general, as shown in Figure 5, a small dose of taxol was sufficient to induce apoptosis in HeLa cells, while retinoic acid did not induce apoptosis even at a higher dose. Thus, this data suggests that retinoic acid did not induce caspase $-3 / 7$ activity in HeLa cells [24]. The finding from this assay suggest that growth suppression induced by retinoic acid does not cause the death of cancer (tumour) cells, but the cells get arrested during the Gl stage of the cell cycle [25].

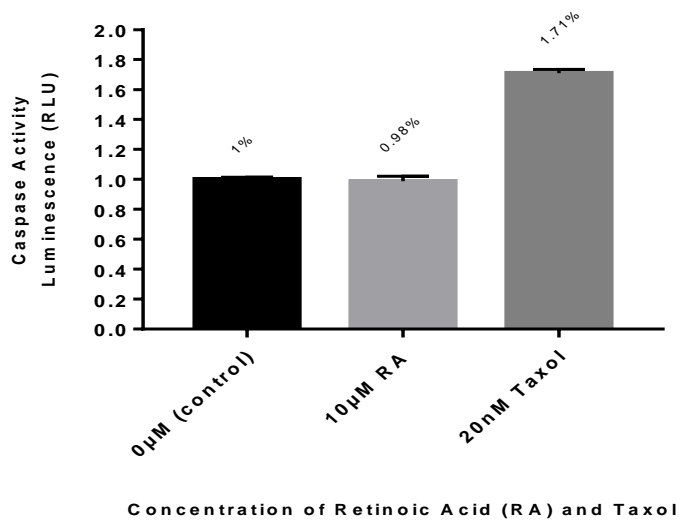

Figure 5 Apoptosis-inducing ability of retinoic acid (RA) and taxol in Apoptosis-inducing ability of retinoic acid (RA) and taxol in Hela cervical cancer cells. Bars are presented as mean \pm SEM $(n=3)$

\subsection{Retinoic Acid Induces Differentiation of Cervical Cancer Cells}

Pan-keratin is an epithelial differentiation marker, and specifically targets luminal epithelial cells. CD133 is a cervical cancer stem cell marker, and highly expressed in HeLa cells that display stem-like characteristics such as differentiation, anti-apoptotic, proliferation, chemo/radio-resistance, self-renewal, and tumorigenicity [9]. SSEA4 is a human embryonic stem cell marker which displays characteristics as indefinite self-renewal and pluripotency [26]. 
Based on Figure 6, upon retinoic acid treatment, the expression of differentiation marker showed an increase in pan-keratin. In contrast, expression of CD133 and SSEA4 decreased. The immunofluorescent staining suggests that, retinoic acid may exert its mechanism by inducing differentiation, and shifts the cervical cancer cells to a more differentiated and less proliferative cell type by up-regulating the differentiation marker (pankeratin), and down-regulating the stem cells markers (CD133 and SSEA4). Previous studies also showed that stem cell markers such as SSEA4 are highly expressed in CSC enriched tumours while differentiation marker, pan-keratin is highly expressed in more differentiated cells [27]. Other studies showed that SP cells express high expression of CD133 marker that were isolated from the HeLa cell line, which shows stem like properties such as self-renewal, proliferation, and differentiation. These SP cells were found to be resistant to chemotherapy [28]. In contrast, SSEA4 expression in general is known to be diminished/down regulated during the differentiation process [29].

Thus, based on the findings of this study, it can be concluded that retinoic acid induced differentiation by shifting cervical cancer cells towards a more differentiated, and less proliferative cell type instead of inducing cell death via apoptosis. As more differentiated cancer cells are often easier to be treated, a second anticancer agent can be used to target, and kill the differentiated CSCs post RA treatment. These findings also show that retinoic acid can be a potent targeted anticancer drug in the treatment of cervical as well as other cancers that are enriched with cancer stemcells (CSCs).
FITC
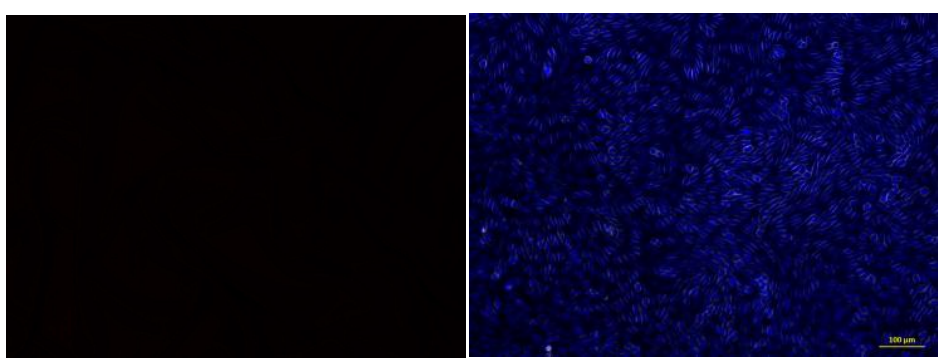

Neaative control

Untreated HeLa cells (merged)

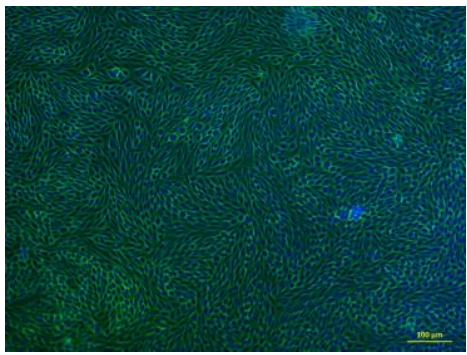

Merged

Treated HeLa cells (merged)

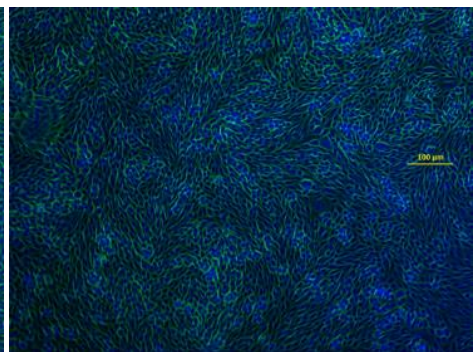

CD133

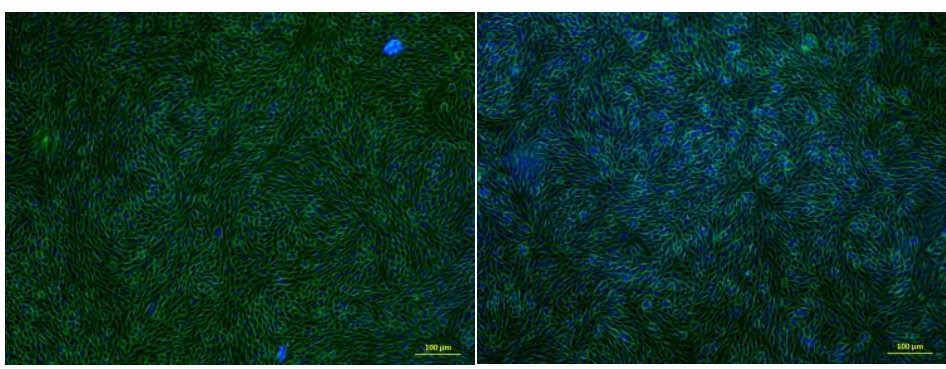

SSEA4

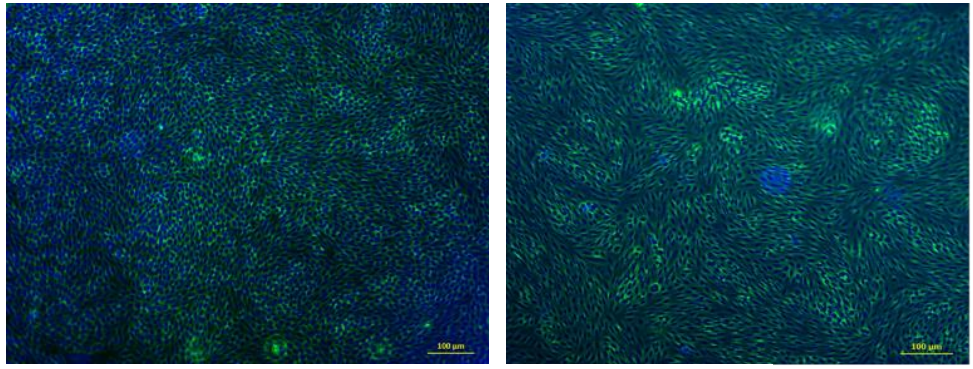

Pan-keratin

Figure $\mathbf{6}$ Retinoic acid influences expression of differentiation marker (pan-keratin) and stem cell markers (CD133 and SSEA4) in cervical cancer cell (HeLa). Stem cell markers were down-regulated after treatment with $10 \mu \mathrm{M}$ of retinoic acids and differentiation marker was increased after the treatment

\subsection{CONCLUSION}

Cervical cancer is a common type of gynaecological malignancy, and can result in death if left untreated. Intra-tumour genetic heterogeneity in cervical cancer leads to metastasis, poor chemo/radio-therapy response, and recurrence of the disease. The major factor that contributes to the recurrence of the cancer in cervical cancer is the presence of cancer stem cell (CSCs). This study showed that retinoic acid exerts anticancer properties by effectively reducing cell proliferation and cell viability of HeLa cells. In addition, a downregulation of cancer stem cell marker and an upregulation of differentiation marker expression as well as morphological changes in HeLa cells in the presence of retinoic acid, correlate well with the significant anticancer properties of retinoic acid. Therefore, the findings of this study show that retinoic acid may potentially serve as a potent targeted therapy for cervical cancer. Thus, retinoic acid in combination with other anticancer drugs might act efficiently, or additively to suppress the growth of tumour/cancer, and provide an effective targeted therapy for cervical cancer. These findings also provide a new avenue for adjuvant treatment in treating cancers that are enriched with CSCs. However, further studies on retinoic acid are required to find the exact mechanism of action for better 
understanding, and improvement of cervical cancer treatment.

\section{Acknowledgement}

The author is thankful to supervisor Dr. Praseetha Prabhakaran for offering advice on this research and for editing the English. Also anonymous reviewers of this manuscript are greatly acknowledged for their critical comments and suggestions.

\section{References}

[1] Muhamad, N. A., Kamaluddin, M. A., Adon, M. Y., Noh, M. A., Bakhtiar, M. F., Ibrahim Tamim, N. S., . . . Aris, T. 2015. Survival Rates of Cervical Cancer Patients in Malaysia. Asian Pac J Cancer Prev. 16(7): 3067-3072.

[2] Altucci, L., Rossin, A., Raffelsberger, W., Reitmair, A., Chomienne, C., \& Gronemeyer, H. 2001. Retinoic Acidinduced Apoptosis in Leukemia Cells is Mediated by Paracrine Action of Tumor-selective Death Ligand TRAIL. Nat Med. 7(6): 680-686. doi: 10.1038/89050.

[3] Bao, B., Ahmad, A., Azmi, A. S., Ali, S., \& Sarkar, F. H. 2013. Overview of Cancer Stem Cells (CSCs) and Mechanisms of Their Regulation: Implications for Cancer Therapy. Curr Protoc Pharmacol. Chapter 14, Unit 14.25. doi: 10.1002/0471141755.ph1425s61.

[4] Braaten, K. P., \& Laufer, M. R. 2008. Human Papillomavirus (HPV), HPV-Related Disease, and the HPV Vaccine. Rev Obstet Gynecol. 1 (1): 2-10.

[5] Crosbie, E. J., Einstein, M. H., Franceschi, S., \& Kitchener, H. C. 2013. Human Papillomavirus and Cervical Cancer. Lancet. 382(9895): 889-899. doi: 10.1016/s01406736(13)60022-7.

[6] Doldo, E., Costanza, G., \& Agostinelli, S. 2015. Vitamin A, Cancer Treatment and Prevention: The New Role of Cellular Retinol Binding Proteins. 2015: 624627. doi: $10.1155 / 2015 / 624627$.

[7] Domingo, E. J., Noviani, R., Noor, M. R., Ngelangel, C. A., Limpaphayom, K. K., Thuan, T. V., ... . Quinn, M. A. 2008. Epidemiology and Prevention of Cervical Cancer in Indonesia, Malaysia, the Philippines, Thailand and Vietnam. Vaccine. 26 (Suppl 12): M71-79. doi: 10.1016/j.vaccine.2008.05.039.

[8] El-Metwally, T. H., Hussein, M. R., Pour, P. M., Kuszynski, C. A., \& Adrian, T. E. 2005. High Concentrations of Retinoids Induce Differentiation and Late Apoptosis in Pancreatic Cancer Cells in Vitro. Cancer Biol Ther. 4(5): 602-611.

[9] Elmore, S. 2007. Apoptosis: A Review of Programmed Cell Death. Toxicol Pathol. 35(4): 495-516. doi: 10.1080/01926230701320337.

[10] Haghshenas, M., Golini-Moghaddam, T., Rafiei, A., Emadeian, O., Shykhpour, A., \& Ashrafi, G. H. 2013. Prevalence and Type Distribution of High-risk Human Papillomavirus in Patients with Cervical Cancer: A Population-based Study. Infect Agent Cancer. 8(1): 20. doi: 10.1186/1750-9378-8-20.

[11] Han, S., Fukazawa, T., Yamatsuji, T., Matsuoka, J., Miyachi, H., Maeda, Y., . . Naomoto, Y. 2010. Anti-tumor Effect in Human Lung Cancer by a Combination Treatment of Novel Histone Deacetylase Inhibitors: SL142 or SL325 and Retinoic Acids. PLOS ONE. 5(11): e13834-e13834. doi: 10.1371/journal.pone.0013834.

[12] Huang, R., \& Rofstad, E. K. 2017. Cancer Stem Cells (CSCs), Cervical CSCs and Targeted Therapies. Oncotarget. 8(21): 35351-35367. doi: 10.18632/oncotarget.10169.
[13] Kreso, A., van Galen, P., Pedley, N. M., Lima-Fernandes, E., Frelin, C., Davis, T., ... O'Brien, C. A. 2014. Self-renewal as a Therapeutic Target in Human Colorectal Cancer. Nat Med. 20(1): 29-36. doi: 10.1038/nm.3418.

[14] Muhamad, N. A., Kamaluddin, M. A., Adon, M. Y., Noh, M. A., Bakhtiar, M. F., Ibrahim Tamim, N. S., . . . Aris, T. 2015. Survival Rates of Cervical Cancer Patients in Malaysia. Asian Pac J Cancer Prev. 16(7): 3067-3072.

[15] Niles, R. M. 2004. Signaling Pathways in Retinoid Chemoprevention and Treatment of Cancer. Mutat Res. 555(1-2): 81-96. doi: 10.1016/j.mrfmmm.2004.05.020.

[16] Ortiz-Sanchez, E., Santiago-Lopez, L., Cruz-Dominguez, V. B., Toledo-Guzman, M. E., Hernandez-Cueto, D., MunizHernandez, S., . . . Garcia-Carranca, A. 2016. Characterization of Cervical Cancer Stem Cell-like Cells: Phenotyping, Stemness, and Human Papilloma Virus Coreceptor Expression. Oncotarget. 7(22): 31943-31954. doi: 10.18632/oncotarget.8218.

[17] Pahlman, S., Ruusala, A. I., Abrahamsson, L., Mattsson, M. E., \& Esscher, T. 1984. Retinoic Acid-induced Differentiation of Cultured Human Neuroblastoma Cells: A Comparison with Phorbolester-induced Differentiation. Cell Differ. 14(2): 135-144.

[18] Prabhakaran, P., Hassiotou, F., Blancafort, P., \& Filgueira, L. 2013. Cisplatin Induces Differentiation of Breast Cancer Cells. Front Oncol. 3: 134. doi: 10.3389/fonc.2013.00134.

[19] Prabhakaran, P., Hassiotou, F., Blancafort, P., \& Filgueira, L. 2013. Cisplatin Induces Differentiation of Breast Cancer Cells. Frontiers in Oncology. 3(134). doi: 10.3389/fonc.2013.00134.

[20] Rostovskaya, M., \& Anastassiadis, K. 2012. Differential Expression of Surface Markers in Mouse Bone Marrow Mesenchymal Stromal Cell Subpopulations with Distinct Lineage Commitment. PLOS ONE. 7(12): e51221. doi: 10.1371/journal.pone.0051221.

[21] Sancho, P., Barneda, D., \& Heeschen, C. 2016. Hallmarks of Cancer Stem Cell Metabolism. Br J Cancer. 114(12): 1305-1312. doi: 10.1038/bjc.2016.152.

[22] Sun, S. Y., \& Lotan, R. 2002. Retinoids and Their Receptors in Cancer Development and Chemoprevention. Crit Rev Oncol Hematol. 41 (1): 41-55.

[23] Truong, T. T., Huynh, K., Nakatsu, M. N., \& Deng, S. X. 2011. SSEA4 is a Potential Negative Marker for the Enrichment of Human Corneal Epithelial Stem/Progenitor Cells. Invest Ophthalmol Vis Sci. 52(9): 6315-6320. doi: 10.1167/iovs.117518.

[24] Vinogradov, S., \& Wei, X. 2012. Cancer Stem Cells and Drug Resistance: The Potential of Nanomedicine. Nanomedicine (Lond). 7(4): 597-615. doi: $10.2217 / \mathrm{nnm} .12 .22$

[24] Wang, K., Zeng, J., Luo, L., Yang, J., Chen, J. I. E., Li, B. I. N. \& Shen, K. 2013. Identification of a Cancer Stem Cell-like Side Population in the HeLa Human Cervical Carcinoma Cell Line. Oncology Letters. 6(6): 1673-1680. doi 10.3892/ol.2013.1607

[26] Wang, L., Guo, H., Lin, C., Yang, L., \& Wang, X. 2014. Enrichment and Characterization of Cancer Stem-like Cells from a Cervical Cancer Cell Line. Mol Med Rep. 9(6): $2117-2123$. doi: $10.3892 / \mathrm{mmr} .2014 .2063$.

[27] Wu, S., Donigan, A., Platsoucas, C. D., Jung, W., Soprano, D. R., \& Soprano, K. J. 1997. All-trans-retinoic Acid Blocks Cell Cycle Progression of Human Ovarian Adenocarcinoma Cells at Late G1. Exp Cell Res. 232(2): 277-286. doi: 10.1006/excr.1997.3495.

[28] Yao, T., Lu, R., Zhang, Y., Zhang, Y., Zhao, C., Lin, R., \& Lin, Z. 2015. Cervical Cancer Stem Cells. Cell Prolif. 48(6): 611 625. doi: $10.1111 / \mathrm{cpr} .12216$. 